\title{
IMPACT OF VARIOUS PARAMETERS OF WATER AND QUALITY SEPARATION INDEX
}

\author{
B.S. Kamble ${ }^{1}$ \\ Mudhoji College Phaltan satara. MS India \\ Corresponding author. balasahebkamblevsrp@gmail.com
}

\begin{abstract}
:
Water is a limited natural resource; therefore preserving water is very important for protection of our environment [M.N. Bharade, S.R.Davane may-june 2015]. Various water quality monitoring systems have been developed to measure concentration of the constituents in quantity for characterization of water for different uses [Shruti shridharan, april 2014]. Water quality can be estimated through quality index, which in turn is analyzed through various parameters such as $\mathrm{pH}$ level, Turbidity, Dissolved Oxygen, Conductivity etc. This paper addresses the impact of parameters on water quality index [Jiauhua dong,2015]. Moreover, this research paper also depicts how water can be utilized based on various values of parameters.
\end{abstract}

Key words: Parameters, $p H$ level, Turbidity, Dissolved Oxygen (DO), Electrical Conductivity (EC), Water Quality Index(WQI)

\section{INTRODUCTION:}

\section{WATER QUALITY INDEX:}

Water Quality Index (WQI) is a measure by which water quality can be estimated for various purposes [Amruta A. Joshi, June 2007]. WOI can be used to predict whether the water is suitable for drinking purpose, industrial purpose or aquatic organisms. WQI can be measured on the scale 0 to 100 . Higher the WQI, better is the quality of water, below are the classification of WQI [dwqi.html-June 2017]: WQI gets affected be various water quality parameters. In this paper effect of $\mathrm{pH}$ level, dissolved oxygen (DO) and electrical conductivity were analyzed.

\section{STUDY AREA}

The groundwater samples were collected from the wells of six places in west Maharashtra dist, Their names, elevations, types of soil, locality of well depth wells and uses of well water are given in Table 1. soils of Satara, Sangali, and Kolhapur were humas rich clayed carbonate mixture called 'Rendzins',. The Soils of Satara., and Sangali were red and that of Kolhapur was back in color it belonged to intra zonal hiolithogehic group of soil that was alkaline with a total nitrogen range from $0.04 \%$ to $0.20 \%$; $1.35 \%$ clayed residues and $1.34 \%$ calcium carbonate. The soils of satara, solapur, pune, nagar were 'Red 'frosialithic' also known as terra rossa. It was a soil ironing rock made up of clayed residues of limestone that was red in colour. It was alkaline with low nitrogen $(0.13 \%)$ and high calcium, magnesium and iron contents. Organic matter of surface soil was around $1.67 \%$ but this percentage decreased with increasing depth (Nair el at, 1996).

\section{WATER QUALITY INDEX (WQI):}

Water quality index of well water was calculated following the procedures and equations given by Horton (1965), Ott (1978), Tiwari and Mishra (1985) and Kaur et.al At (2001) With slight modifications. To calculate WQI, fifteen parameter of water were selected. These were $\mathrm{pH}$, BOD oxygen total dissolved solids (TDS), total hardness $(\mathrm{TH})$, total alkality (TA), total chlorine (TD), Nitrate Phosphorus (p) manganese (Mn) Chromium, copper iron (Fe) and zinc ( $\mathrm{Zn})$. The unit of weight (w) of all Factors was calculated in table 2

$\mathrm{W}_{1}=\frac{k 1}{v 1} \quad \ldots .(1) \quad \mathrm{W}_{1}-$ weight of comical factor $\mathrm{V}_{1}-$ Standard limits $\mathrm{K}_{1}$ Constant of proportionality Value of $\mathrm{K}$ was Calculated as $\mathrm{K}=\frac{1}{15}-(2)$

The Word unit weight simples relative use of each of the factor in a unit water quality and is 
department an the on standard describe unit in water as prescribed the $\mathrm{pH}$, TDS, TH, Cl, F, $\mathrm{NO}_{3} \mathrm{Fe}, \mathrm{Zn}$, by WHO (1984), for DO, TC, P, Mn by Renn(1970) and tfer cr, cu, by BIS (1983) (Table -2) futures having low permissible limit can have the quality of water to a large extent went on a slight increase and such factors have high weighting on the other hand factors which have higher permissible limits have low weightings (Kaur et, al 2001) Regarding rating scale each factor had been assigned a rating value $(\mathrm{Vr})$ to calculate WQI the Values tell between of 100 to assign rating value to a factor, range of its concentration in water was divided to five in intervals the rating $\mathrm{Vr}=0$ that chemical factor exceeded standard (desirable) limit and water was polluted, while $\mathrm{Vr}=100$ implied that chemical factor had the most desirable value and the water has clam the other rating falling between these two categories condition of water (Table 3)

To calculate WQI, the products of rating (Vr) and Unit weight (wi) of all 15 factors were summated

WQI $=\sum v r x w i \ldots \ldots . . .(3)$ Water quality index was calculated in this way the well water of all six places WQI failing withing the range of 0-39.99 stood for severally polluted water 60-79.99 for moderately polluted water between 80-99.99 for strongly pointed water and 100 for absolute clean water (Table-4)

\section{RESULT AND DISCUSSION:}

The physico-chemical factors of well water analyzed during November 2016 to March. 2017 in six places in West Maharashtra Together with the average value of each factor. Its SO and coefficient variation $(\mathrm{CV})$ are presented Table 5.The water temperatures averaged $15.1^{\circ} \mathrm{C}$ and there were only very little variations in temperature between stations. This could be attributed to rainy and winter seasons that prevailed during the period of investigation. The $\mathrm{pH}$ of water samples of all stations was alkaline and it ranged from 7.8 to 8.7 . The desirable limit for $\mathrm{pH}$ is 7.0-8.5 which is a safe range for drinking (WHO. 1984). In the present study the $\mathrm{pH}$ of well Waters of Kolhapur (8.6) and pune (8.7) exceeded this limit, Generally $\mathrm{pH}$ of ground water is influenced by geology of catchment area and buffering capacity of water (Waber and Stum, 1993).Higher $\mathrm{pH}$ reduces the germicidal potentiality of chlorine and induces the formation of toxic trihalomethanes (Trivedy and Goal. 1986). According to European economic community report (Indirabai and George, 2002), the permissible standard for drinking water for dissolved oxygen (DO) is $5 \mathrm{pm}$ and above, and Renn (1970) postulated $6 \mathrm{ppm}$ and above as the standard desirable limit of oxygen for water, but this value varies depending upon water temperature and the partial pressure of oxygen in its gas phase. The DO of well water at all six places were above $7 \mathrm{ppm}$. The high level of oxygen could be due to the mixing, of rain water rich in oxygen with the ground water The electrical conductivity, total dissolved solids and total hardness of the well waters of all places except that of Solapur were within the standard desirable limits set for natural waters. By WHO (1984) (EC: 1400pmho/cm; TDS: 1000ppm; total hardness: $500 \mathrm{ppm})$. In Solapur, the values of these parameters exceeded far higher than the desirable limits. Srinivas et al., (2000) opined that the higher value of $\mathrm{EC}$ in groundwater is due to the high dissolved solids which may subscribe to the conductivity and has a direct bearing on the percentage of total solids. High TDS may be due to groundwater pollution by waste waters which is discharged into pits, ponds and lagoons and migrate down the water table (Rani et aL, 2003). This may be true in the case of the well water of Solapur where large heaps of cattle and human wastes water of satara, where large heaps of cattle and human wastes were see' dumped around the area where the well was located. The main sources of hardness in water are sedimentary rocks, seepage and run-off from soils and hardness 
mainly originates in areas with thick top soil and limestone formation (Sawyer and McCarty, 1967) a condition that prevailed in Solapur and to some extent in Pune, where the soils were red ferrosialithic. Renn (1970) stated that hardness in groundwater is also due to the addition of calcium and magnesium ions to a natural water system as it passes through soils and rocks containing large amounts of these elements in mineral deposit. Alkalinity in water provides an idea of natural salts present in it. The standard desirable limit of alkalinity in potable water is $120 \mathrm{ppm}$ (WHO, 1984) and the values of this parameter in well waters of all six places exceeded this limit. The cause of alkalinity is the minerals which dissolve in water from soil, The various ionic species that contribute to alkalinity include bicarbonate, hydroxide, phosphate, borate and organic acids and these factors are characteristic of the source of water and natural processes taking place at any given time (Sharma, 2004). The presence of chlorine in concentrations above $0.5 \mathrm{ppm}$ in natural waters should be considered evidence of pollution (Renn, 1970). In the present study the total chlorine in well waters ranged from $0.03 \mathrm{ppm}$ in Satara) to $0.08 \mathrm{ppm}$ in and Solapur. The permissible unit chloride in drinking water is 250ppm (WHO, 1984). Except Susa (1540ppm), the chloride of well waters of all other places were within the prescribed desirable limit. The well waters of elevated places like sangali $(809 \mathrm{pm})$ and kolhapur $(60 \mathrm{ppm})$ recorded the minimum concentrations of chloride. The presence of chloride in large amounts in the well water of satara may be an indication of pollution from seawater, since it is located very near to the Fluoride and nitrate of well waters were within the desirable limits set for them $(1.5 \mathrm{ppm}$ for fluoride and $50 \mathrm{ppm}$ for nitrate) by WHO (1984). Fluoride with 0.6 to $1.2 \mathrm{ppm}$ is regarded as an essential constituent of drinking water mainly because of its role in prevention of dental caries (McClure, 1970). High nitrate values in ground water are possibly due to organic and sewage pollution and in the present study. The well water of only Solapur (42.09 ppm) recorded higher nitrate content. The values of phosphorus, iron and zinc recorded in the well waters were not of any concern and were within the prescribed limits set for them by WHO (1984), Renn (1970) and BIS(1983) manganese and chromium were detected only in to the well of Nagar however the value to copper recorded in the well water of satara (0.262 pdm) (BIS, 1983) and the value of the same recorded in the well water of El- mag(o.046) was almost near to the permissible limit the values of copper recorded for the same in the well waters situated on the western side of Maharashtra To assess the origin of sources, the parametric rate of hardness of water with other parameter were tabulated and the result are presented in table6 ration of TDS chlorine, fluoride, nitrate, phosphorus, manganese, chromium, copper, iron and zinc in relation to hardness of water had high co-efficient of variation values, when compared with the $\mathrm{Vr}$ value of hardness (63.12) this suggest that all the above factors originated form sources different form that of the hardness. The water quality index (WQI) well water of six places in west Maharashtra to gather with their designators and quality of water presented in table-7 the well waters satara (WQI) 87.94 and kolhapur (WQI) 84.90 were singly pointed and were good for drinking. Except for alkalify all other parameters studied in these two places were well within their standard desirable limit modestly polluted well water were in Satara (WQI-72-90) Pune and Nagar they reduce suitable water treatment of the well water Solapur (WQI) 59.46 however was excessively polluted and was not potable the water was much polluted and west unsafe term public health and its strongly concentrated, The people should not be allowed to drink water form well as a precaution measure. There is an increasing awareness amount of the west Maharashtra to 
maintain the well water at their highest quality and purity level and it is hoped that the present study may be prove to be an use the tool in minting the water quality.

\section{CONCLUSION}

It is possible to synthesize $\mathrm{Sn}$ doped $\mathrm{CdO}$ thin films at low substrate temperature using advanced spray pyrolysis technique. The structural and optical properties were seen to be strongly dependent on 'Sn' doping concentration. Pure $\mathrm{CdO}$ and $\mathrm{Sn}$ doped $\mathrm{CdO}$ thin films were found to have polycrystalline nature It was also seen that with 'Sn' doping the (111) peak got strongly enhanced, while the intensity of other peaks remained almost constant indicating that one can grow highly oriented films along a preferred direction using advanced spray pyrolysis technique. The films grown at low substrate temperature and at different doping concentrations have size of the order of few nanometers. The film deposited at 3 at \% Sn doping $\left(\mathrm{S}_{3}\right)$ is highly oriented along (111) plane and exhibits good crystallinity. FESEM analysis of CdO films support the XRD analysis and confirm that the films are polycrystalline having granular morphology and could be useful for gas sensing applications. Optical properties show that films are transparent to visible light, with a direct band gap $\sim 2.4-2.6 \mathrm{eV}$.

\section{REFRENCES:}

M N barabde, S R Danve, “ continuous water quality monitoring system for water resources at remote places: international journal of engineering research and general science, Vol.2, no.3, Part 2, MayJune 2015 , ISSN 2091- 2730.

Shruti sriddaran, "water quality monitoring system using wireless Sensor Network", International journal of advanced research in electronics and communication engineering (IJARECE), Vol. 2, no, 3, pp. 399-402, April 2014, ISSN: $2278-909 X$
Jianhua Dong, Guying Wang et al, "A survey of samr water quality monitoring system", Springer- Verlag Berlin Heidelberg, 2015, DOI $10.1007 *$ s 1 1356-014-4026-X

Amruta Amit Joshi, "Water Quality monitoring system using Zing-Bee and solar power supply", International Journal of Advance Research in Electrical, Electronics and Instrumentation Engineering (An ISO 3297: 2007 Certified Organization) Vol.4

http://www.mag.gov.nl.ca/waterres/quality/dri nkingwater/dwqi.html, Accessed on 7 JUNE, 2017

Adak, M.D. and K.M. Purohit: Assessment of the water quality in rajgangpur industrial complex - part 1: Physicochemical parameters and water quality index (2003)

APHA: Standard Method for examination of water and wastewater, American public health association, Washington (1989)

BIS: Standard for water for drinking and other purpose. Bureau of Indian standard publication, New Delhi (1983)

Horton, R.K: An index number system for rating water quality J. Wat Horton, R.K.: an index number system for rating wter quality. J.wat pollute. CountFed. 37. 300306 (1965)

Indirabai. W.P.S and S. George: Assessment of drinking water quality in selected areas of Tiruchirappalli town after flood Poll. Res. 21(3). 243-(2002)

Kaur. H.J Syal and S.S. Dillon: Water Quality index of the river satlu. Poll. Res 20(2), 199-204 (2001).

McClure, F.1.: Water fluoridation. U.S. Dept. Edu. Welfare. MK Washington (1970).

Nair, GA, F.F. El•Tourni, K.M.A. EI: rayed, A.M. Bosnian and K.C. Skim: Habitat occurrence and density of some putmonate slugs of north-east Libya (Monism Milacidae and timacidae). J. Mr. Zool...1t0, 251.2S6 (1996). 
B.S Kamble and A.P Acharya, Stydy of biological assessment and physiochemical parameters of bhima basin river in dryand wet season EDU WORLD ISSN 23197129 volume IX No.2 Page 101-105

Ott W R.: Environmental indices - Theory and practice. Arm Arbor Pubs... 3.202413 (1978).

Rani. D.F.G., S. Georg and J. Barraza: The drinking water quaky characterizes of five rural places in and around Ibittagudi, Tamil Nadu. India. Fret. Res... 22(4 111115 (2003).

Renn C.E.: Investigating water Wigan\& Educational products division, La Molts chemical products company. Maryland 11970).

Sawyer C.N. and P.L. McCarty Chemistry of sanitary engineers. '.trciraw Hill. Now York (1967).
Sharma. MR Assessment of ground water quality of Harnepur area in ifirnachat Pradesh. Pot. Res.,

shrinivas. C.H. R.S Piska, C. Venicateshwar. M.S.S. Rao and P.R, fi, leciy Studies on groundwater quality of Hyderabad. Pout nest... 1912). 285-289 (2000)

Tiwari. T.M. andmishra: A preliminary assigniner: .31 KA: 114.01101 and is to major inrkan rivers. Ind. J Env. Prow, 5(4). 276-'271 UM)

Trivedy. R.K and P.K. Goal. Chemical and biological rnelhotls orator pollJrion studies. Err irmenental publication. Kanrd 1986

Weber. W.J. Jr. and W. Stun' Mocnanisrn of hydrogen ion turlerieg...n natural waters. J. Amer. Water Midis Assn., 55, 15s31558 (1963).

WHO Guidelines for drinking water waft, Vol 1 Cletnmmendations $\quad$ W.H.O... Geneva (1984).

TABALE :1 DISTRICT PLACES OF WELL WATER COLLECTION IN WEST MAHARASHTRA.

\begin{tabular}{|l|c|l|l|c|l|}
\hline $\begin{array}{c}\text { Name of } \\
\text { Place }\end{array}$ & Elevation(m) & Type of soil & $\begin{array}{c}\text { Locality } \\
\text { of well }\end{array}$ & $\begin{array}{c}\text { Depth of well } \\
(\mathbf{m})\end{array}$ & \multicolumn{1}{|c|}{ Use of well water } \\
\hline Satara & 340 & Rendzinas & Farm & 248 & $\begin{array}{l}\text { Drinking, domestic, } \\
\text { livestock, agriculture }\end{array}$ \\
\hline Sangali & 600 & Rendzinas & Residental & 300 & Drinking and domestic \\
\hline Kolhapur & 625 & Rendzinas & Residental & 310 & Drinking and domestic \\
\hline Solapur & 90 & $\begin{array}{l}\text { Red } \\
\text { Ferrosialithic }\end{array}$ & Farm & 42 & Livestock, agriculture \\
\hline Pune & 40 & $\begin{array}{l}\text { Red } \\
\text { Ferrosialithic }\end{array}$ & Residental & 200 & $\begin{array}{l}\text { Drinking domestic, } \\
\text { livestock agriculture }\end{array}$ \\
\hline Nagar & 26 & $\begin{array}{l}\text { Red } \\
\text { Ferrosialithic }\end{array}$ & Residental & 200 & $\begin{array}{l}\text { Drinking domestic, } \\
\text { livestock agriculture }\end{array}$ \\
\hline
\end{tabular}


TABLE - 2: WATER QUALITY FOCTOR THEIR STANDARD AND ASSIGNED UNIT WEIGHTS.

\begin{tabular}{|c|l|l|l|}
\hline Sr.No. & Water quality factors & $\begin{array}{l}\text { Standard } \\
\text { (Desirable limits) }(\text { Vi) }\end{array}$ & Unit weights (Wi) \\
\hline 1 & $\mathrm{pH}$ & $<7.0-8.5>$ & 0.0020 \\
\hline 2 & Dissolved oxygen, & $>6.0 \mathrm{ppm}$ & 0.0025 \\
\hline 3 & $\begin{array}{l}\text { Total dissolved solids } \\
\text { (TDS) }\end{array}$ & $<1000 \mathrm{ppm}$ & 0.000015 \\
\hline 4 & Total hardness & $<50 \mathrm{D} \mathrm{ppm}$ & 0.000030 \\
\hline 5 & Total alkalinity & $<120 \mathrm{ppm}$ & 0.00013 \\
\hline 6 & Total chlorine, & $<0.50 \mathrm{ppm}$ & 0.0300 \\
\hline 7 & Chloride & $<250 \mathrm{ppm}$ & 0.000060 \\
\hline 8 & Fluoride & $<1.50 \mathrm{ppm}$ & 0.0100 \\
\hline 9 & Nitrate & $<50 \mathrm{ppm}$ & 0.00030 \\
\hline 10 & Phosphorus, & $<0.10 \mathrm{ppm}$ & 0.1503 \\
\hline 11 & Manganese, & $<0.10 \mathrm{ppm}$ & 0.1503 \\
\hline 12 & Chromium, & $<0.05 \mathrm{ppm}$ & 0.3006 \\
\hline 13 & Copper, & $<0.05 \mathrm{ppm}$ & 0.3006 \\
\hline 14 & Iron & $<0.30 \mathrm{ppm}$ & 0.0500 \\
\hline 15 & Zinc & $<5.0 \mathrm{ppm}$ & 0.0030 \\
\hline
\end{tabular}

Source WHO (1984), ${ }^{2}$ Renn (1970), ${ }^{3}$ BIS (1983)

TABLE- 3 RATING VALUS FOR DIFFERENT FACTORS TO CALCULATE WQI

\begin{tabular}{|c|l|l|l|l|l|l|}
\hline S.r No. & \multicolumn{1}{|c|}{ Factors } & & \multicolumn{1}{c|}{ Ranges } & & \\
\hline 1 & $\mathrm{pH}$ & $70-85$ & $8.6-8.7$ & $8.8 .-8.9$ & $9.0-9.2$ & $>9.2$ \\
\hline & & & $6.8-6.9$ & $67 .-6.8$ & $6.5-6.7$ & $>6.5$ \\
\hline 2 & $\begin{array}{l}\text { Dissolved } \\
\text { oxygen }\end{array}$ & $>6.0$ & $5.1-6.0$ & $4.1-5.0$ & $3.1-431$ & $>3.0$ \\
\hline 3 & $\begin{array}{l}\text { Total dissolved } \\
\text { solids (TDS) }\end{array}$ & $0-250$ & $251-500$ & $501-750$ & $751-1000$ & $>1000$ \\
\hline 4 & Total hardness & $0-125$ & $126-250$ & $251-375$ & $376-500$ & $>500$ \\
\hline 5 & Total alkalinity & $21-50$ & $51 .-70$ & $71-90$ & $91-120$ & $>120$ \\
\hline 6 & Total Chlorine & $0-0.13$ & $0.14-0.26$ & $0.27-0.39$ & $0.40-0.50$ & $>0.50$ \\
\hline 7 & Chloride & 0.60 & $61-120$ & $121-180$ & $181-250$ & $>250$ \\
\hline 8 & Fluoride & $0-0.4$ & $0.41-80$ & $0.81-1.20$ & $1.21-150$ & $>1.50$ \\
\hline 9 & Nitrate & 0.13 & $14-26$ & $27-39$ & $40-50$ & $>50$ \\
\hline 10 & Phosphorus & $0-0.025$ & $0.26-0.050$ & $0.051-0.075$ & $0.076-0.1$ & $>0.1$ \\
\hline 11 & Manganese & $0-0.025$ & $0.013-0.24$ & $0.051-0.075$ & $0.076-0.1$ & $>0.1$ \\
\hline 12 & Chromium & $0-0.012$ & $0.08-0.14$ & $0.025-0.036$ & $0.037-0.50$ & $>0.05$ \\
\hline 13 & Copper & $0-0.012$ & $0.13-0.24$ & $0.025-0.036$ & $376-500$ & $>0.05$ \\
\hline 14 & Iron & $0-0.07$ & $0.07-0.14$ & $0.15-0.21$ & $91-120$ & $>0.30$ \\
\hline 15 & Zinc & $0-1.25$ & 1.26 .250 & $2.51-3.75$ & $376-500$ & $>5$ \\
\hline & Ratings (Vr) & 100 & 80 & 60 & 40 & $>0$ \\
\hline
\end{tabular}


Table No 4 Physico- comical Parameter of West Maharashtra

\begin{tabular}{|c|c|c|c|c|c|c|c|c|c|c|c|c|c|c|}
\hline Places & Tmpt & $\mathrm{pH}$ & DO & EC & TDS & $\begin{array}{l}\text { Total } \\
\text { Hard } \\
\text { ness }\end{array}$ & $\begin{array}{l}\text { Alka } \\
\text { lity }\end{array}$ & $\mathrm{Cl}$ & $\mathrm{Cl}^{-}$ & $\begin{array}{l}\text { Flori } \\
\text { de }\end{array}$ & $\begin{array}{l}\text { Nitrat } \\
\text { e }\end{array}$ & $\mathbf{P}$ & Fe & $\mathrm{Ni}$ \\
\hline Satara & 15.3 & 6.2 & 7.6 & 1039 & 832 & 291 & 246 & 0.03 & $\begin{array}{l}19 \\
0\end{array}$ & 0.10 & 15.50 & 0.09 & $\begin{array}{l}0.0 \\
5 \\
\end{array}$ & 0.52 \\
\hline Sangali & 15.2 & 6.5 & 6.3 & 600 & 488 & 255 & 231 & 0.06 & 80 & 0.11 & 7.09 & 0.05 & $\begin{array}{l}0.0 \\
2 \\
\end{array}$ & 0.17 \\
\hline Kolhapur & 15.0 & 8.5 & 8.4 & 689 & 487 & 210 & 220 & 0.06 & 60 & 0.01 & 21.21 & $\begin{array}{l}00.0 \\
9 \\
\end{array}$ & $\begin{array}{l}0.0 \\
7 \\
\end{array}$ & 0.27 \\
\hline Solapur & 15.0 & 7.8 & 7.0 & 5760 & 4610 & 813 & 270 & 0.08 & $\begin{array}{l}15 \\
40\end{array}$ & 0.87 & 42.09 & 0.03 & $\begin{array}{l}0.1 \\
2\end{array}$ & 0.00 \\
\hline Pune & 15.1 & 6.7 & 6.3 & 981 & 784 & 330 & 255 & 0.08 & $\begin{array}{l}16 \\
0\end{array}$ & 0.19 & 5.76 & 0.02 & $\begin{array}{l}0.0 \\
4\end{array}$ & 0.00 \\
\hline Nagar & 15.0 & 8.4 & 8.5 & 900 & 720 & 252 & 213 & 0.05 & $\begin{array}{l}16 \\
0\end{array}$ & 0.15 & 21.26 & 00 & $\begin{array}{l}0.0 \\
5\end{array}$ & 0.00 \\
\hline
\end{tabular}

TABEL NO 5 PARAMETRIC RATION BETWEEN HARDNESS AND OTHER PARAMETER OF GROUND WATER OF WEST MAHARASHTRA

\begin{tabular}{|l|l|l|l|}
\hline Sr.No & Parametric Ratio & \multicolumn{1}{c|}{ SD } & \multicolumn{1}{c|}{ CV } \\
\hline 1 & $\mathrm{pH} / \mathrm{H}$ & 0.0015 & 6.42 \\
\hline 2 & $\mathrm{DO} / \mathrm{H}$ & 0.0026 & 11.65 \\
\hline 3 & $\mathrm{TDS} / \mathrm{H}$ & 7.15 & 194.121 \\
\hline 4 & $\mathrm{Alk} / \mathrm{H}$ & 0.08 & 12.61 \\
\hline 5 & $\mathrm{Chlorine} / \mathrm{H}$ & 0.000088 & 52.69 \\
\hline 6 & $\mathrm{Chloride} / \mathrm{H}$ & 2.55 & 250.82 \\
\hline 7 & Fluoride/H & 0.00144 & 211.04 \\
\hline 8 & $\mathrm{NO}_{3} / \mathrm{H}$ & 0.05 & 111.92 \\
\hline 9 & $\mathrm{P} / \mathrm{H}$ & 0.000133 & 118.75 \\
\hline 10 & $\mathrm{Mn} / \mathrm{H}$ & 0.000530 & 381.29 \\
\hline 11 & $\mathrm{Cr} / \mathrm{H}$ & 0.0000133 & 238.35 \\
\hline 12 & $\mathrm{Cu} / \mathrm{H}$ & 0.000402 & 169.62 \\
\hline 13 & $\mathrm{Fe} / \mathrm{H}$ & 0.000133 & 79.64 \\
\hline 14 & $\mathrm{Zn} / \mathrm{H}$ & 0.000663 & 182.64 \\
\hline
\end{tabular}


TABLE NO.6 WATER QUALITY INDEX OF WELL WATER OF DIFFERENT PLACES IN WEST MAHARASHTRA

\begin{tabular}{|l|l|l|l|l|}
\hline Sr.No & Places & WQI & Designation & Inference \\
\hline 1 & Satara & $72-90$ & Class II & Moderately Polluted \\
\hline 2 & Sangali & $87-94$ & Class I & Slightly Polluted \\
\hline 3 & Kolhapur & $84-90$ & Class I & Slightly Polluted \\
\hline 4 & Solapur & $59-46$ & Class III & Excessively Polluted \\
\hline 5 & Pune & $66-86$ & Class II & Moderately Polluted \\
\hline 6 & Nagar & $78-92$ & ClassII & Moderately Polluted \\
\hline
\end{tabular}

TABLE NO. 7 CLASSIFICATION OF WATER QUALITY INDEX

\begin{tabular}{|l|l|l|l|l|}
\hline Sr.No. & $\begin{array}{l}\text { Water } \\
\text { Quality } \\
\text { Index }\end{array}$ & Water Quality Status & Class & Grades \\
\hline 1 & $0-20$ & Worst Water Quality & VII & Highly Polluted \\
\hline 2 & $0-44$ & Poor Water Quality & VI & Severely Polluted \\
\hline 3 & $45-64$ & Marginal Water Quality & V & Excessively Polluted \\
\hline 4 & $65-79$ & Fair Water Quality & IV & Moderately Polluted \\
\hline 5 & $80-88$ & Good Water Quality & III & Slightly Polluted \\
\hline 6 & $89-84$ & Very Good water Quality & II & Clean \\
\hline 7 & $95-100$ & Excellent Water Quality & I & Absolutely Clean \\
\hline
\end{tabular}

